\title{
JUDICIAL CONTROL OF LEGISLATION IN THE BRITISH EMPIRE
}

\author{
Herbert A. SMith
}

The discussions on sovereignty which were so prominent in the times of Austin and his successors have in our own day gone somewhat out of fashion, and the tendency of modern writers is to maintain that the word "sovereignty" is too ambiguous to form a profitable subject of legal analysis. I venture to think that in some respects this tendency has gone too far. Different theories of sovereignty have actually exercised a most important influence upon the practical solution of problems of government, and in particular upon the problem of the relation of the courts to legislation.

In the United States the theory that sovereignty resides only in "the people" is indicated with sufficient clearness in the preamble to the constitution and in the tenth amendment. So far as the federal constitution is concerned, the doctrine has been suffered to remain expressed in general terms, and no attempt has been made to indicate with precision the agencies through which the sovereignty of the people may find its legal expression. In a number of individual states the problem has been worked out in greater detail, and an effort has been made to give a legal form to the doctrine of popular sovereignty in the constitutional provisions for the initiative, referendum, and recall. Both in the federal and in the state constitutions the practical result of the doctrine is to be found in the general agreement that the powers of all legislatures are inherently and essentially limited in relation to the subject-matter of legislation itself. American political theory has not contented itself with asserting that doctrine of the distribution of powers which is necessary to any truly federal system of government. It has gone farther, and has continually assumed that there are certain activities which lie outside the proper province of all legislative bodies. A general acceptance of this theory appears in nearly all the political writings of the revolutionary period, and it has found expression in judicial opinions almost from the beginning of the Republic. When Marshall rendered his classic decision in Marbury v. Madison ${ }^{1}$ the political criticism of the day was directed, not against the claim of the Supreme Court to define and limit the powers of Congress, but against its alleged encroachment upon the proper-field of the executive power. From the time of the revolution down to our own day a distrust of legislative activity has exercised a marked influence over all American thought and action, and the more recent constitutions of some states have given a legal expression to this distrust in an extreme form which would

\footnotetext{
${ }^{1}$ (1803, U. S.) I Cranch, I37.
} 
have been neither dreamed of nor tolerated by Hamilton and his contemporaries.

In sharp contrast with this doctrine the constitutional development of Great Britain and of all the British Dominions has proceeded since the middle of the eighteenth century upon the theory of the sovereignty of parliament. The sovereignty of the people is not denied in our modern political thought, but it is regarded as a principle of politics rather than as a rule of constitutional law. The will of the people can only find legal expression through the acts of the legislature, and the duty of the legislature to obey the will of the people is a duty imposed, not by law, but by political morality and practical expediency.

So far as the parliament of Great Britain is concerned little need be said. More than three hundred years have passed since Coke delivered himself of his well-known dictum that the courts could declare null a statute which violated "common right and reason." This theory obtained a certain amount of political currency in the seventeenth century and was not without its influence upon the political thought of the American revolution, but no English court of law has ever ventured in practice to assume such a liberty, and the government of the country has proceeded uniformly upon the principle laid down by Blackstone ${ }^{2}$ in unqualified terms, that "the power of parliament is absolute and without control." In the more pungent language of a modern judge ${ }^{3}$ it is said that "the legislature cannot make evil good, but it can make it not actionable."

The modern development of completely autonomous legislatures in the overseas Dominions has created new problems. Previous to the establishment of the Dominion of Canada in 1867 the doctrine of parliamentary sovereignty supplied a means for controlling colonial legislatures by executive action which rendered it seldom necessary to invoke the assistance of the courts of law.

If the cabinet in London considered that any particular colonial statute was undesirable on grounds of policy, they could abrogate it either by refusing the royal assent or by disallowing it after it had passed. If they deemed it desirable as a matter of policy, but were doubtful about the competence of the colony to enact it; then the difficulty could be solved by the aid of an imperial statute. Whatever happened the whole matter was under the effective control of the executive authorities in London, and in practice it was hardly ever necessary to bring the question before the courts.

\footnotetext{
${ }^{2}$ I Cooley's Blackstone (2d ed. 1872) I59; see also Bonham's Case (1610, K. B.)

8 Co. Rep. II3b, II8a, and 4 Coke, Institutes (I79r) 36.

3 Farwell, L. J., in Conway v. Wade [1908, C. A.] 2 K. B. $844,856$.

- In a few instances in the eighteenth century the Privy Council declared colonial statutes to be ultra vires. It must, however, be remembered that at that time the Privy Council was as much an executive as a judicial body.
} 
A statute of $1696^{5}$ had. declared that colonial legislatures were unable to legislate in a manner repugnant to any English statute extending to the colony concerned, but apart from this the exact nature of the powers possessed by the colonial assemblies was never precisely defined. Down to the middle of the nineteenth century a vague theory prevailed that a colony could not pass statutes at variance with the principles of the common law. This doctrine, which seems to have been' founded upon a hazy recollection of Coke's dictum, was much too ill-defined to form the subject of judicial decision, and I am not aware of any instance in which a colonial statute was declared null upon these grounds. Whatever it may or may not have meant, it was finally disposed of by the Colonial Laws Validity Act of $1865,{ }^{\circ}$ which explicitly declared that no colonial statute should be deemed void by reason of repugnance to the common law, unless it contravened the provisions of an imperial statute extending in express terms to the colony concerned.

When a federal system of government was set up in Canada by the act of $1867^{7}$ it soon became apparent that the interpretation of the new constitution was going to provide plenty of work for the courts. It became necessary to consider the essential nature of legislative power in the overseas Dominions and to determine whether the doctrine of parliamentary sovereignty was confined to the parliament of Great Britain and Ireland, or whether it had been successfully transplanted across the oceans to the ends of the earth. After some years of discussion, this issue was presented squarely to the Privy Council in the classical case of Hodge v. The Queen. ${ }^{8}$ A statute of the Ontario legislature ${ }^{9}$ had created a board of license commissioners with power to define offences and prescribe penalties for their violation, and the appellant contended that a provincial legislature had no right to delegate to a subordinate body the functions entrusted to it by the imperial parliament. He claimed that the legislature of Ontario itself was no more than a local delegate of the sovereign assembly at Westminster, and that therefore it was bound to observe the classical maxim-delegatus non potest delegare. This contention was overruled by the Privy Council in language which has now gained a permanent place in the literature of our constitutional law.

"It appears to their Lordships," said Sir Barnes Peacock,"10 "that the objection thus raised by the appellants is founded on an entire misconception of the true character and position of the provincial legislatures. They are in no sense delegates of or acting under any man-

${ }^{5} 7 \& 8$ Will. III, c: 22 , sec. 9.

28 \& 29 Vict. c. 63, sec. 3 .

'30 \& 3 I Vict., c. 3.

${ }^{8}$ (I884, P. C.) L. R. 9 A. C. II7.

'Rev. Sts. Ont. 1877 , c. I8I.'

${ }^{10}$ L. R. 9 A. C. at p. 132 . 
date from the Imperial Parliament. When the British North America Act enacted that there should be a legislature for Ontario, and that its legislative assembly should have exclusive authority to make laws for the Province and for provincial purposes in relation to the matters enumerated in section 92, it conferred powers not in any sense to be exercised by delegation from or as agents of the Imperial Parliament, but authority as plenary and as ample within the limits prescribed by section 92 as the Imperial Parliament in the plenitude of its power possessed and could bestow. Within these limits of subjects and area the local legislature is supreme and has the same authority as the Imperial Parliament."

In 1885 the same doctrine was re-affirmed in the Australian case of Pozell v. Apollo Candle Co., ${ }^{11}$ and it has long since become part of the current coin of constitutional discussion in the British Empire.

It will easily be seen that this acceptance of the theory that sovereignty is an attribute of all legislatures results in a severe limitation of the function of the courts. Under the American practice the courts may declare a statute to be null on one of two grounds. In the first place, they may consider that the legislature has invaded the area reserved by the constitution to another. Secondly, they may declare that the subject matter of the statute is one wholly beyond the competence of any legislative body, and is therefore reserved under the federal tenth amendment or under the state constitution to the sovereign people itself. In other words, they are concerned, not only with preserving the proper distribution of legislative power, but also with defining its essential nature.

Where the theory of parliamentary sovereignty prevails, the second of these functions disappears. In Canada or Australia the work done by the courts in applying the constitution substantially consists in seeing that the various legislatures do not trespass upon each other's territory. So long as they keep off one another's preserves they can do what they please within their own field. In the eye of the law there is no "sovereign people" which has jealously retained for itself certain powers that it will not entrust to any legislative assembly. The sovereignty of the-people is a political fact of which the law takes no account, and there is no matter in the whole range of human activity which may not lawfully be dealt with by some law-making body. The courts have merely to determine which is the proper legislature to deal with the subject matter of the particular case at bar.

The practical consequences of this doctrine will be readily appreciated by the American reader who is familiar with the actual operation of judicial control as practiced in his own country. For example. no argument based upon the doctrine of the "separation of powers" could be successfully addressed to any tribunal in the British Empire in attacking the validity of a legislative act. The attempt has been

11 (1885, P. C.) I. R. 10 A. C. 282. 
made, but has been signally defeated. In 1875 the Parliament of Canada passed an act ${ }^{12}$ establishing a Supreme Court for the Dominion, and one of the provisions required the judges to give advisory opinions upon questions of law submitted to them by the executive governmentprecisely what the judges of the United States Supreme Court had refused to do in $1793^{13}$ In I9I I the validity of this provision was attacked at the instance of some of the provincial governments, and the matter came up before the Privy Council. ${ }^{14}$ The appellant provinces argued that the effect of this enactment was to deprive the Supreme Court of its purely judicial character by compelling it to act as an advisory committee of the executive. The language of Lord Loreburn in delivering the opinion of the Judicial Committee is of sufficient importance to be quoted at some length.

"It is argued," he said, "15 "that the Dominion Act authorizing questions to be asked of the Supreme Court is an invasion of provincial rights, but nof because the power of asking such questions belongs exclusively to the Provinces. The real ground is far wider. It is no less than this-that no legislature in Canada has the right to pass an Act for asking such questions at all. This is the feature of the present appeal which makes it so grave and far-reaching. It would be one thing to say that under the Canadian Constitution what has been done could be done only by a provincial legislature within its own Province. It is quite a different thing to say that it cannot be done at all, being, as it is, a matter affecting the internal affairs of Canada, and, on the face of it, regulating the functions of a court of law, which are part of the ordinary machinery of government in all civilized countries .......

"In the interpretation of a completely self-governing Constitution founded upon a written organic instrument, such as the British North America Act, if the text is explicit the text is conclusive, alike in what it directs and in what it forbids. When the text is ambiguous, as for instance, when the words establishing two mutually exclusive jurisdictions are wide enough to bring a particular power within either, recourse must be had to the context and scheme of the Act. Again, if the text says nothing expressly, then it is not to be presumed that the Constitution withholds the power altogether. On the contrary, it is to be taken for granted that the power is bestowed in some quarter unless it be extraneous to the statute itself (as, for example, a power to make laws for some part of His Majesty's dominions outside of Canada) or otherwise is clearly repugnant to its sense. For whatever belongs to self-government in Canada belongs either to the Dominion or to the Provinces, within the limits of the British North America Act ..... .

"What in substance their Lordships are asked to do is to say that

${ }^{12}$ In its present form the statute is now Rev. Sts. Can. 1906, c. I39.

${ }^{13}$ See Thayer, Legal Essay's (1908) 53, and cf. Hayburn's Case (1792, U. S.) 2 Dall 409; see also the letter of the Justices of the circuit court for the district of Pennsylvania to the President of the United States, April I8, 1792, 2 Dall. 4 II.

14 Att'y-Gen. for Ontario v. Att'y-Gen. for Canada [1912, P. C.] A. C. 571.

${ }^{18}$ Ibid. at p. 58I et seq. 
the Canadian Parliament ought not to pass laws like this because it may be embarrassing and onerbus to a Court, and to declare this law invalid because it ought not to have been passed. Their Lordships would be departing from their legitimate province if they entertained the arguments of the appellants. They would really be pronouncing upon the policy of the Canadian Parliament, which is exclusively the business of the Canadian people, and is no concern of this Board. It is sufficient to point out the mischief and inconvenience which might arise from an indiscriminate and mischievous use of the Act, and leave it to the consideration of those who alone are lawfully and constitutionally entitled to decide upon such a matter."

So far as the issue is one of strict law, such language really removed the principle of parliamentary omnipotence from the area of debate. But there is usually also a political background to the debates on constitutional questions which are staged in the courts of law, and it may be convenient here to refer to this aspect of the matter. The constitution of the United States was a compromise embodying the maximum of verbal agreement that could be attained between two fiercely opposed schools of political thought. Its real meaning was left to be worked out by subsequent discussion, and the independence of the country made it necessary for the questions in dispute to be settled by a purely domestic tribunal. In these circumstances it was inevitable that the actual power of decision should fall into the hands of men who had taken an active part in the political controversies. When Marshall passed from the federal cabinet to the Supreme Court bench he could not and did not leave his political opinions in the desk of his executive office. He merely gave expression to them through a new medium. In saying this we need not suggest that he was a partial or an unscrupulous judge, but merely that he was sufficiently human to retain a lively interest in the political development of his country. Fortunately his views coincided with the real needs of the United States, and for this reason his work on the bench became part of the permanent structure of the constitution. Had his office been filled at the time by a lawyer of different outlook and personality it is probable that the history of judicial control in the United States might have run a very different course.

In Canada also there was a lively, though rather less acrimonious, conflict between the federalist and the provincial points of view, but the relation of the country to Great Britain caused the questions at issue to be settled in a very different atmosphere. The legal problems presented to the Privy Council in the first twenty years after confederation were largely the expression of a personal struggle between Sir John Macdonald, the first prime minister of Canada, and Sir Oliver Mowat, the equally able premier of Ontario. In the debates which preceded confederation Macdonald had not concealed his own preference for a purely unitary scheme of government, and only accepted the federal solution as the best which could be obtained in the cir- 
cumstances. As Premier of Canada he pressed strongly for the view that the Dominion Parliament was the only truly sovereign legislature in Canada, and that the provincial bodies were rather on the footing of municipal councils enjoying only delegated powers. This doctrine was condemned in Hodge $v$. The Queen, ${ }^{16}$ and on the whole Mowat was the winner in the long struggle. But the Canadian solution differed from the American in that the last word lay with men who had played no part in Canadian political controversy. The English and Scotch lawyers who sat round a table in an obscure room off Whitehall to decide the nature of Canadian federalism were able to regard the issues presented to them with an air of Olympian detachment. No less than in the case of Marshall or Taney the personal mentality and political upbringing of the Judicial Committee largely determined the current of their judicial decisions. But in this personal outlook there was nothing Canadian. As young men they had learned the orthodox doctrine of sovereignty from Blackstone and Austin, and their whole life's work was carried on under the shadow of an omnipotent legislature. The instrument which they had to interpret declared in its preamble that Canada was to have a constitution "similar in principle to that of the United Kingdom," and the doctrine of parliamentary sovereignty formed the very foundation of all British constitutional theory. To the political controversies three thousand miles away they were entirely indifferent, and the vigorous language of Canadian newspapers was only very faintly echoed in the formal arguments presented in the cool atmosphere of the council chamber. The American constitution they looked upon as a novel and curious experiment in government to be studied mainly for the interest of noting its divergence from the principles with which they were familiar. Their function was to establish'firmly upon Canadian soil that doctrine of parliamentary sovereignty which was of the very essence of British institutions.

In the thirty-three years which separated the Canadian from the Australian constitution this fundamental principle was so well settled as to be placed almost beyond the reach of argument. The Australians deliberately rejected the Canadian in favour of the American model when they decided that the general residue of undefined powers should rest with the States rather than with the Commonwealth, but they followed the accepted British doctrine in refusing to admit any sovereignty of "the people" that did not find expression in the acts of some legislature. ${ }^{17}$ The text of the constitution practically eliminates appeals from the Commonwealth High Court to England in constitutional cases, but the doctrine of Hodge $v$. The $Q u e e n^{18}$ has been accepted

\footnotetext{
${ }^{10}$ Supra note 8.

${ }^{17}$ The special provisions for taking a referendum upon proposed amendments to the constitution do not conflict with this general principle.

${ }^{18}$ Supra note 8.
} 
in full by the Australian courts. "The Federal Parliament," said Mr. Justice Higgins, "has, within its ambit, full powers to frame laws in any fashion, using any agent, any agency, any machinery that in its wisdom it thinks fit, for the peace, order, and good government of Australia."19 As in Canada, the judges are not empowered to limit the exercise of legislative power except in so far as they may be compelled to define the agencies through which it may be exercised.

The South African constitution of Igog needs little comment, since the South Africans deliberately abandoned the federal idea and created a purely unitary scheme of government. Except for certain temporary restrictions there is no constitutional limitation of any kind upon the legislative power of the Union Parliament, and the provincial councils are entirely at the mercy of the Parliament, which can enlarge, restrict, or even abolish their powers at its sole discretion. From this it follows that in South Africa the courts have really no more right to interfere with legislative activity than they have in Great Britain.

So far we have seen the current of constitutional development run evenly and without deflection. With the constitution of the Irish Free State, ${ }^{20}$ established by joint action of the Irish and British legislatures in I922, a new element appears. It need hardly be said that the constitution-makers of Dail Eireann had no particular reverence for British institutions, except in so far as they considered their utility to have been proved by practical experience, and we shall not be surprised to find that they were willing to seek inspiration from other sources.

The preamble begins by proclaiming the doctrine of popular sovereignty in the form that "all lawful authority comes from God to the people," but it will be noted that here again there is no reservation of any powers to "the people" that cannot be expressed through appropriate legislative forms. A very real limitation of legislative power is contained in the proviso which follows, to the effect that the whole instrument and any laws made under it must be construed with reference to the Anglo-Irish treaty of I92I and are void in so far as they are in conflict with that agreement. As a matter of history we know that this limitation was inserted under pressure from England, and it would presumably be disregarded if at any time Dail Eireann chose to take the view that the treaty had ceased to be binding.

The sixth and seventh articles of the constitution provide for liberty of the person and the inviolability of the dwelling, but since each of these liberties is qualified by the words "except in accordance with law," there is presumably no real limitation of legislative power. Furthermore there is a significant reservation of the right to take any military action which may become necessary during a state of war or armed rebellion.

${ }^{10}$ Baxter v. $A h W a y$ (1909, H. Ct. Aust.) 8 Comm. L. R. 626, 646.

I2 \&.13 Geo. V, sess. 2, c. I. 
The eighth article contains a definite guarantee of freedom of conscience and worship, qualified only by the words "subject to public order and morality." It goes on to prohibit in unqualified terms all forms of religious endowment or religious discrimination, and is a real abridgment of the power of the legislature, though of course it could be abolished by constitutional amendment, if the treaty with Great Britain should ever cease to be operative. The limitation has been drafted with a careful attention to detail which will probably serve to eliminate the difficult problems that have arisen under the more loosely worded prohibitions in some American state constitutions.

The right of free speech and public meeting is preserved by the ninth article in so far as it is employed "for purposes not opposed to public morality." In practice it may be expected that this article will not seriously interfere with any powers which the legislature may wish to exercise, since the courts will undoubtedly hold that the legislature is the sole judge of what comes under the head of "public morality."

The tenth article declares, without going into detail, that all citizens have the right to free elementary education, and the eleventh prohibits the legislature from alienating the public domain for any longer period than ninety-nine years.

The forty-third article prohibits the passing of ex post facto laws in criminal matters, and the seventy-second preserves the right of trial by jury in criminal cases of the graver kind.

Taking these provisions as a whole, we see at once a faint reflection of the American doctrine of limited legislative power as compared with the strict theory of British parliamentary sovereignty. But the American reader who compares these restrictions with the long list of prohibitions addressed to his own legislatures by the federal and state constitutions will be more impressed by the Irish unwillingness to impose any checks upon the power of lawmaking which are at all likely to be seriously felt in practice. The significance of this decision will be the more apparent when it is remembered that the draftsmen of the Irish constitution did not share the traditional reverence of the Canadians and Australians for British institutions, but were rather concerned to emphasise the independent character of their own work. Since no questions of a federal nature can arise in the Free State, we may expect that in practice the Irish judges will have little or no opportunity of actually controlling the decisions of the legislature. Except for the limitation imposed by the terms of the treaty with Great Britain, the full doctrine of parliamentary sovereignty has been substantially preserved.

Broadly speaking, it is true to say that the "British Commonwealth of Nations," ${ }^{21}$ notwithstanding the immense diversity of its constituent

2 This phrase has now obtained legal recognition through its adoption in the - Irish Constitution. 
elements, has been practically unanimous in rejecting the theory that it is the function of the courts to protect "the people" from the encroachments of the legislature. Whether this theory be right or wrong, it clearly must stand as an original contribution to political thought of distinctively American origin. Under the British scheme of government the general doctrine is that the judges have no control over the policy of Parliament, except when they are called upon to decide between the conflicting claims of rival legislatures in a federal system. If they hold that a particular statute is ultra vires, then the result automatically follows that it must fall within the proper competence of some other assembly. The current of law-making power may be diverted, but it cannot be prevented from flowing, as soon as it has found its proper channel, and the only real corrective for legislative folly is that which the suffrage places in the hands of the people themselves. 